\title{
"Mother Ireland, get off our backs":" \\ Gender, Republicanism and State Politics in Prison Short Stories by Northern Irish Women Writers
}

\author{
Mercedes del Campo del Pozo \\ University of Ulster, Northern Ireland
}

Copyright (c) 2014 by Mercedes del Campo del Pozo. This text may be archived and redistributed both in electronic form and in hard copy, provided that the author and journal are properly cited and no fee is charged for access.

\begin{abstract}
Looking into prison short fiction, this article discusses how a number of Northern Irish women writers have challenged male-centred narratives of the Troubles. Mary Beckett, Frances Molloy and Brenda Murphy have created alternative discourses of political violence which differ from the dominant narratives of incarceration. They confront established discourses of masculinity and femininity by subverting social constructs of gender, particularly the models of the rebel-hero and Mother Ireland ingrained in the nationalist/republican traditions. Their prison short stories are excellent examples of how state politics is superseded by gender politics in women's writing and they are also proof of an emerging gender consciousness that challenged dominant readings of the Troubles in the last decades of the twentieth century.
\end{abstract}

Key Words. Northern Ireland, the Troubles, prison, gender, women writers, short fiction.

Resumen. A través del análisis de relatos de temática carcelaria este artículo examina cómo algunas escritoras norirlandesas se enfrentan a las narraciones del conflicto contadas desde un punto de vista masculino. Mary Beckett, Frances Molloy y Brenda Murphy crean discursos nuevos de violencia política que difieren de las narraciones carcelarias hegemónicas. Estas tres escritoras afrontan los discursos de masculinidad y feminidad establecidos socavando las construcciones sociales de género, en particular los modelos de "héroe rebelde" y "Madre Irlanda" arraigados a las tradiciones nacionalista y republicana. Sus relatos son buenos ejemplos de cómo la política de estado es reemplazada por una política de género. Además, nos muestran el surgimiento de una conciencia femenina que se contrapone a las lecturas dominantes del conflicto durante las últimas décadas del siglo XX.

Palabras clave. Irlanda del Norte, conflicto, prisión, género, escritoras, relatos breves.

1. In the documentary Mother Ireland (Anne Crilly 1988), Mairead Farrell says that when she was in Armagh Jail she and her fellow prisoners used this phrase (Lyons 1996: 141).

The dominant discourses of incarceration in Northern Ireland, those of the republicans and the British state, have been mainly malecentred. Like in other public discourses of the Troubles, women have had little part in these narratives which "either omi[t] the experiences and actions of women or se[e] those experiences and actions as fundamentally undifferentiated from the actions and motivations of men in their communities" (McAuliffe 2010: 171). A number of academics, however, have looked at incarceration from an alternative perspective in which gender "interlink[s] with these powerful and competing 'constructions' of the same history" (McAuliffe 2010: 171). Elizabeth Shannon's I Am of Ireland (1989) and Eileen Fairweather et al.'s Only the Rivers Run Free (1984) explore the Troubles through interviews 
with women from different social, political and religious backgrounds. These feminist studies cover a wide range of issues and although imprisonment is one of them, they only discuss it in some sections. On the contrary, Megan Sullivan's Women in Northern Ireland focuses entirely on the topic of incarceration. She examines its cultural representations in female non-fictional, film and literary narratives, but she does not include short fiction as part of those literary narratives. Other academics have focused exclusively on women's direct experiences of imprisonment. Nell McCafferty, a feminist journalist who was a delegate of the Armagh Prisoners' Solidarity Committee, published The Armagh Women in 1981, the year in which the prison protests culminated with the second hunger strike. Her book seems factual but it has a feminist agenda. McCafferty centres on the idea that nationalism is a feminist issue, an opinion to which many feminists were hostile. Similarly, in her article "It Is My Belief That Armagh Is a Feminist Issue" she urges the women's movement to support Armagh prisoners on the basis that their struggle $i s$ a feminist matter. Margaret D'Arcy's Tell Them Everything was published the same year as The Armagh Women and has similar feminist objectives. D'Arcy, a feminist playwright with a strongly republican family background, ${ }^{2}$ spent three months in Armagh Jail for refusing to pay a fine for demonstrating outside Armagh Jail on International Women's Day. Tell Them Everything is an account of her time in Armagh with the republican women on no-wash protest. Despite the republican prisoners' request to 'tell everything' when she was released, D'Arcy failed to put them on centre stage. Her account is self-centred and extremely subjective as she talks about her own experience rather than the experiences of the prisoners. Her deliberate efforts to enter Armagh and be moved to A Wing as well as her determination to fit in and participate in the protest make us have reservations about her neutrality. References to romantic notions of Irish nationalism (claims of unconditional solidarity, the use of terms such as "revolutionaries" and "young warriors" or allusions to

2. Her father was in the IRA and fought in the War of Independence and the Irish civil war. to Celtic mythological figures) also evidence lack of impartiality in her supposedly factual account. Mary Corcoran, on the other hand, has published factual and detached research about female political prisoners. ${ }^{3}$ Her study Out of Order (2006), the most comprehensive research on this matter to date, combines theory, history and sociology in order to analyse political imprisonment for women in Northern Ireland at different stages of the Troubles. The shortcoming with factual narrations like this, however, is that they cannot provide new avenues of understanding female imprisonment because they can only adhere to facts.

The nature of creative writing enables to explore subject-matters at a deeper psychological level. Although the studies mentioned above have been vital to acknowledge the experiences of Northern Irish women with regards to incarceration, I believe that the short stories analysed in this article manage to throw new light on this socio-political phenomenon. Women writers' prison short stories not only rectify women's general marginalisation in prison literary narratives but also subvert romantic distortions of Irish republicanism like those we encounter in D'Arcy's book. Unlike D'Arcy's and McCafferty's publications, they do not have a specific feminist agenda that favours republican ideology, which is indeed undermined and pushed into the background. Although the stories raise gender issues and are influenced by feminist concerns, they are not strictly feminist narratives.

Wire wives' survival: ${ }^{4}$ Mary Beckett's "The Master and the Bombs" and Frances Molloy's "The Man of the House" and "Dancing with My Daddy"

Internment was implemented from time to time in the North and the South of Ireland as a political and military strategy to suppress the militant republican movement since partition.

3. She has published various articles on women's imprisonment in Northern Ireland: "Normalization and its Discontents: Constructing the 'Irreconcilable' Female Political Prisoners in Northern Ireland" (2007); “"We had to be stronger': The Political Imprisonment of Women in Northern Ireland, 1972-1999"' (2004).

4. Prisoners' wives were commonly known as 'wire wives' or 'prison widows'. 
This measure was mainly enforced during the Irish Civil War (1922-1923), the Second World War (1939-1945), and the IRA border campaign of 1956-1962. The implementation of internment in Northern Ireland and the Republic of Ireland during the 1950s undermined the IRA border campaign, which was "eventually abandoned in February 1962 due to a lack of public support" (Maguire 2008: 1). Mary Beckett's "The Master and the Bombs", which was written a year after the end of this terrorist campaign (Parker 1995: 7), is set in this context. Although her story illustrates that lack of support for militant republicanism, her discourse differs substantially from the public discourse in that she puts gender and material conditions before politics.

Frances Molloy's "The Man of the House" and "Dancing with My Daddy" also deal with pre-Troubles interment but contrary to Beckett's "The Master and the Bombs", they were written in the 1980s in the midst of the Troubles. ${ }^{5}$ The British and Unionist governments reintroduced internment in 1971 in order to "secur[e] the preservation of the peace and the maintenance of order in Northern Ireland" (McKearney 2011: 34). However, internment in the Northern state had the opposite effect to what the government expected; it did not crush the IRA or decree violence but instead it contributed to their growth. The indiscriminate arrests and continuous raid harassment in the republican areas, along with the brutal interrogation methods employed in suspects, resulted in fierce opposition to internment among the Catholic population, who saw it as a political tool used against their community. In prison, political prisoners enjoyed a relatively relaxed incarceration regime until March 1976, when special category status was withdrawn. Everyone convicted of terrorist related crimes from that date was regarded as an ordinary criminal and had their privileges as political prisoners removed. ${ }^{6}$ Their prison conditions changed drastically, which provoked a lot of tension between the republican population and

5. They were published posthumously in 1998 but Gerard Brady, in his introduction to Women Are the Scourge of the Earth, dates their composition to the 1980s. the British authorities. The issue of criminalisation of political prisoners became a very delicate issue and it is probably for this reason that Molloy sets her stories during preTroubles internment. Whilst still maintaining a connection with the present situation, she can effectively focus on the plight of the prisoners' families without appearing trivial for not addressing the distressing situation of the prisoners on protest.

A study about the attitudes towards internment published by Fortnight in 1974 two years before internment was abolished showed the differences of opinion between the nationalist and unionist communities in the first decade of the Troubles. While 95\% of the Catholic minority opposed imprisonment without trial, only $47 \%$ of the Protestant majority disapproved of it, some of them affirming that even though it was an injustice, it was "under the present circumstances a necessary evil" (1974: 6). Rather than positioning their narrative within these sociopolitical views, Beckett and Molloy adopt a gendered discourse that centres on the injustices done to the prisoners' families. These writers denounce the financial strain and the emotional trauma that the internees' dependants were put under. The female characters in their stories are more concerned with the daily realities confronting their families than with political principles and thus, the material conditions are brought to the fore while the political confrontation between nationalists and the British state is relegated to the background.

Beckett's "The Master and the Bombs" is about an unhappy married couple who use the political situation of the late 1950s as an excuse to become estranged. The narrator is married to Mathew, a school teacher who is arrested when explosives are found in his school. His wife maintains that he is not responsible for the explosives; he has only claimed responsibility so as to abandon his obligations as a father, husband and breadwinner for a "nice peaceful

6. Political prisoners were allowed to wear their own clothes, associate freely and organise their own activities. Moreover, they did not have to do prison work and had fifty percent remission of their sentences. 
cell where nobody will expect anything from him" (1980: 104). Gender juxtaposes and even counters nationalism in this story. The narrator's tone carries a trace of sarcasm that results from her annoyance at her husband's cowardice shown in his reluctance to face reality. Her sarcasm conveys that she is the active member of the family when according to social expectations she should not be. By desiring that Matthew acts in a more manly way and that she has an exclusively passive role she seems to be embracing traditional gender roles; however, Beckett is in fact challenging traditional notions of gender. The marital circumstances between the narrator and the school teacher are an ideal opportunity to parody the social constructs of masculinity and the rebel-hero. Matthew is going to be seen as a brave Irish rebel imprisoned on political charges when in reality he is a coward who cannot confront his domestic obligations. The narrator makes a clear difference between the old revolutionaries of the beginning of the twentieth century and the militant republicans of the 1960s, who are portrayed in a far less heroic light. Matthew has no political interests but takes advantage of the political circumstances to evade domestic responsibilities. His mock-heroic image is pitiful, making of the narrator the real long-suffering heroine.

Frances Molloy's "The Man of the House" and "Dancing with Daddy" also ridicule nationalism. The stories centre on two disempowered children who suffer "at the hands of the powerful" adults who control their lives (Carr 1998: 14) and explore the consequences of their fathers' internment, which adds a considerable burden to their already difficult family situations. Their fathers' incarceration runs parallel to these children's social and familial entrapment. As in "The Master and the Bombs", the heroes in Molloy's stories are not the internees but those who confront life outside the prison bars.

"The Man of the House" is a poignant story that recounts a boy's futile efforts to persuade his mother to sign his father out of prison so that his disabled brother is not taken away. 'Signing out' was a release mechanism by which pre-Troubles internees could obtain freedom if they signed a document declaring that they would not resume subversive activities. Few made use of this opportunity because those who 'signed out' were often "regarded as unprincipled and were ostracised by their comrades" (Maguire 2008: 37). In Beckett's "The Master and the Bombs" and more explicitly in Molloy's "The Man of the House" the internees and their wives refuse to resort to this practice too; however, their motives are personal instead of political. In Molloy's story the mother insinuates that her husband would like to 'sign out' but is waiting for her to ask him. In this manner he can hold her responsible for his desertion without damaging his republican reputation. Ironically, she also has the same double-standards as her husband. Her disgust at her brother-in-law's disloyalty for 'signing out' when he was interned may initially appear to show strong nationalist convictions but we soon realise that she is more concerned about appearances than political ideologies. She has decided to wait until her husband is let out - preferring her disabled child to be taken away - because she does not want others to say that she "didn't do [her] bit for the cause" (1998b: 69). Hence, her apparent wholehearted nationalism, like her husband's, is only pretence to keep a good reputation in front of her neighbours. The victims in the story are undoubtedly the children, who pay a high price for their parents' egocentric responses to the political situation, basing their decisions on romantic conceptions of the republican struggle rather than on what is best for their family.

Molloy's other prison short story, "Dancing with My Daddy", is an epistolary narration about the growing friendship between two pen pals in 1957. The story consists of a series of letters between a ten-year-old girl called Kate and her father's prison cell mate Danny, the youngest internee in Crumlin Jail. The two young protagonists exchange letters in which they recount various anecdotes that reveal how they are coping with their particular circumstances, Danny inside prison and Kate at home and in school. Kate and her mother are depicted as the real heroines of the story. Their endurance and struggle for survival are more admirable than the qualities required of Danny and the other internees, who only have to handle boredom. Although internment is an important part of "Dancing with My Daddy", it is hardly discussed in political terms. This is because the female characters' concerns are not related to political ideologies but to their domestic and gender realities, which are 
presented as legitimate affairs that matter as much as (if not more than) any political creed. Despite the confinement and the monotony, life for the political prisoners is easy compared to what life is like outside prison for Kate and her mother. Internees have no responsibilities within prison, their only concern being a dance party on Christmas Eve. Through Kate's letters we catch a glimpse at her mother's day-to-day domestic struggle to bring up and look after a large family on her own. Danny does not only admit that "[1]ife can't be easy for her on her own" (1998a: 49) but also that life for the internees is much easier than for Kate, her mother and his sister, who have the full and exhausting responsibility of looking after - or helping to look after - the family. Internees, he says, "lead a charmed life compared to [them]" (1998a: 49).

The image of the republican rebelhero/martyr-hero is contested and deconstructed by the wire wives in Beckett's and Molloy's prison short stories. These characters do not regard their husbands as criminals (following the state discourse) nor as heroes (following the republican discourse). The internees in "The Master and the Bombs" and "The Man of the House" might be held in high esteem by their neighbours because of their supposedly republican heroism but are regarded as cowards by their wives. Although the prisoners in "Dancing with Daddy" are not depicted in the same light, the juxtaposition of the relaxed prison regime with their families' hardship outside the bars challenges idealised discourses of male republican heroism and martyrdom. Internees' prison life is relatively easy compared to the struggle of their families outside. Prisoners do not have to attend to family responsibilities; it is women who are left alone to cope with domestic duties, children, prison visits, and financial difficulties. As a result of these experiences of incarceration, some women in Northern Ireland began to discern the ironies of male republican heroism. In Begoña Aretxaga's Shattering Silence (1997) a woman asserts that the choice to participate in militant republicanism always has an "element of selfishness". She states that the man "gets the inner satisfaction of his decision, the comradeship, the education in jail, and the social recognition, they still are the heroes. Women have to carry on with the less heroic task of looking after the children, make ends meet and sustain emotionally their men. And they don't get the recognition" (1997: 121). Beckett's and Molloy's prison short stories do recognise these women's difficulties, breaking a silence that unfortunately has predominated in Northern Irish prison narratives.

Although the lives of the female characters in these stories are inevitably informed by the Northern Irish political context, their concerns are closer to domesticity and quotidian life. "The Master and the Bombs", "The Man of the House" and "Dancing with Daddy" shift from the political context of internment to gender and material conditions. Perceptions on motherhood and reproduction are explored and challenged through the political climate of the 1950s. Through Beckett's and Molloy's stories we are made aware of a problem that affected many women in those years. Contraception was not socially acceptable and lack of birth control meant that women usually had a lot of children. Since the Catholic Church strongly opposed the use of contraceptive methods, the only way to avoid undesirable pregnancies for practising Catholics was to avoid sexual intercourse. Although Catholic morality regarded women as primarily child-bearers, the Catholic Church had ironically denied them control over that role (Fairweather 1984: 111). Molloy and Beckett know that lack of reproductive choice is a problem for women, especially if they do not have their partners' support. Male incarceration increased the heavy domestic burden that women already had looking after large families of young children. Hence, Beckett's and Molloy's prison short stories not only subvert male-centred discourses of the Troubles, but they also confront patriarchal discourses about gender roles, motherhood and female reproduction.

\section{Women prisoners and the symbolism of menstrual blood in Brenda Murphy's "Human Waste" and "A Curse"}

The withdrawal of special category status in 1976 resulted in a series of protests to obtain political status again. Male republican prisoners went on the blanket protest, the no-wash protest and two hunger strikes in 1980 and 1981. Female prisoners' protests in Armagh Jail developed in a similar direction. Their no-wash protest began in February 1980 when they were not permitted access to toilet facilities for three days as a punishment for a violent confrontation 
with male officers who brought some of them to disciplinary hearings by force. While the 'dirty' protest in Long Kesh and Armagh Jail went on, several men and three women went on the first hunger strike. The no-wash protests in both prisons ended in December 1980 so that all the attention could go to the second hunger strike in which only male prisoners participated. Despite the parallels between male and female prisoners' protests for political status, women's actions were largely ignored. Even today Northern Irish prison narratives have generally excluded women prisoners' experiences. Brenda Murphy's "A Curse" (1985) and "Human Waste" (1988) are the only two narratives that explore this topic in fiction. Written in the aftermath of the prison protests, these short stories reflect on the experiences of female prisoners' political as well as gender struggles during the Troubles.

There were two dominant discourses of incarceration after the withdrawal of political status. The discourse of the British authorities was based on the criminalisation of those prisoners convicted of terrorist related crimes, a decision supported by the Northern Irish state. In their eyes, the conflict in Northern Ireland was not a war but a break-down in law and order and therefore, they could not regard prisoners as POWs (prisoners of war). Republican prisoners, however, wanted to be recognised as political prisoners or POWS, not as ordinary criminals, so they started a series of prison protests to show their rejection of criminalisation. With regards to the no-wash protest, prisoners in Long Kesh and Armagh Jail always stated that they were forced into it by the prison authorities. On the contrary, the authorities argued that the conditions the prisoners lived in were self-imposed. Many including part of the Catholic population - felt uneasy about the use of bodily waste as weapons for political resistance. The massive support for the prisoners - national and international - did not begin until they went on hunger strike. For this reason, Murphy's choice of subject-matter in "Human Waste" is unusual. Writing about an unpleasant topic like the nowash protest is challenging in itself; writing about the female prisoners' no-wash protest is both challenging and provocative because, as Aretaxga explains in her article "Dirty Protest", "if the Dirty Protest was incomprehensible, the women's was unthinkable, generating in many men, even among the ranks of supporting Republicans, reactions of denial" (1995: 129).

Although Murphy seems to favour the republican discourse of decriminalisation, she also challenges both the British and republican attitudes to women in "A Curse" and "Human Waste", two apparently nationalist narratives that emphasise gender as a more fundamental concern. Murphy's nationalism is informed by gender and therefore state politics is ultimately superseded by gender politics. Her stories lay bare the different layers of oppression of nationalist women, not only as political prisoners by the British authorities but also for their female condition by both a patriarchal state system and male-centred republicanism. Despite having been a republican prisoner, Murphy has been critical of the republican movement in her writing - in particular with regards to gender and sexual difference - and "Human Waste" is no exception. "Human Waste" is inspired on her own experiences of the no-wash protest in Armagh Jail. This story is not only a factual account about the nauseating effects of the 'dirty' protest; it is also a political statement in terms of republicanism and above all gender. The story concludes with a political statement that rejects the criminalisation of political prisoners: "They'll have to admit we're different" (1988: 55). The adjective 'different' not only acknowledges the republican discourse of decriminalisation but also implicitly echoes gender difference. Republican women did not only fight politically against the prison authorities but also confronted patriarchal attitudes both within the established estate and the republican movement.

In the story the media coverage of Long Kesh contrasts with the lack of information about Armagh prison. The protagonist's mother only knows how bad the situation is in Armagh because she can relate her daughter's protest to the male prisoners' no-wash protest. But Armagh women are not only ignored by the media, men also turn a blind eye to their protest; the other female prisoner in the story complains that her father "won't even mention it" (1988: 54). A woman surrounded by her bodily waste and her menstrual blood was at odds with the traditionally gentle, passive, and maternal image expected of her gender. Protesting prisoners in Armagh crossed the boundaries of what was considered feminine 
and therefore it was preferable for some to ignore a protest which made them 'less of a woman' in the eye of a strongly patriarchal society. Laura Lyons argues that Armagh women on no-wash protest used menstruation to politicise their bodies, refusing to let that part of their female condition be apolitical (1996: 122). Northern Irish society, however, struggled to accept menstruation as a part of these women's 'dirty' protest. The ambiguous 'it' that the prisoner's father will not mention refers as much to the protest as to menstruation. The fact that this conversation comes after the protagonist tells her about her mother's preoccupation that she might get an infection when she is on her period suggests that the father is deliberately ignoring that aspect of the female protest too. In "BBlood on the Walls": Gender, History and Writing the Armagh Women", Mary McAuliffe and Laura Hale explain that although the political agenda was the same, men's and women's no-wash protests were perceived differently, a "distinction ... based on sexual difference, which centred on the unspeakable: women bleeding and women's blood" (2010: 181). Protesting female prisoners encountered opposition from their communities and the republican movement, who discouraged them to get involved in the no-wash protest as a result of that distinction. In Aretxaga's Shattering Silence, a woman talks about her brother's disapproval of her participation in the no-wash protest:

He would say 'Come off. It's not right for a woman to do this!' Sinn Fein would say 'Don't do that. It's easier on men.' They didn't want us on dirt protest because of our periods. They didn't say that; they said that we were women, that we were different. But we knew it was because of our periods. These were men who had killed, and had been imprisoned and they couldn't say the word 'period' (1997: 127).

These words help to shed light on the symbolism of menstruation in Murphy's prison short stories. As the menses is an integral part of the female condition, it highlights sexual difference in both stories.

"A Curse" is set in a detention centre and relates a woman's humiliating experience when her period arrives while she is in custody and the police officers show no sympathy for her distress. The story is not just a reflection on the powerlessness of confinement but also a fierce criticism of women's social repression. The protagonist's menstruation defies a prison system mainly designed for and by men because, as Esther Aliaga points out, it emphasises her female condition over her prisoner status (1992: 83). ${ }^{7}$ The woman's confrontation with the policeman illustrates how her menstruation complicates gender politics and state politics within prison institutions. The socially constructed dichotomy between security forces and republicanism is superseded by something much more fundamental: gender. Her menstruation emphasises her gender, thus making the policeman uncomfortably aware that her detention does not match the traditional model of femininity, a model in which his wife is categorised. As the detainee cannot ascribe to that model, the policeman's rejection is categorical: she is "the definite Other. A sexual and political Other" (Aliaga 1992: 84). ${ }^{8}$ This is because, as Sarah Edge explains,

[w]omen's involvement and interest in national identity struggles ... disrupts traditional and dominant ideologies surrounding femininity on a number of levels. Women who are involved in violence disrupt dominant ideologies of the feminine as passive and peace-loving. Similarly, women's involvement in the public world of politics disrupts ideologies surrounding women's space in the private world of home and family (1995: 176).

Hence, the female detainee in Murphy's story is not only being oppressed ideologically by the state but also as a woman by patriarchal constructions of femininity.

The female officer she deals with later in the story is not much more sympathetic than the policeman. She takes the detainee to a lavatory, gives her a sanitary towel and repeatedly tells her to "hurry up" (1985: 41). The lavatory has a toilet, a urinal, and a wash basin but the toilet is blocked and there is no soap, hot water, or towels. Desperate, the woman appeals to the officer's womanhood but encounters a rejection

\footnotetext{
7. Murphy does not specify whether the protagonist is republican or loyalist; however, because of the writer's own political background, it is likely that she is a republican prisoner. By not identifying her as one or the other, Murphy is making emphasis on her gender rather than her ideology.
}

8. "el Otro definitivo. Un Otro político y sexual" 
of "female solidarity" (Pelan 2005: 72). The female officer - her equal in gender terms does not patronise her as the policeman does; she simply ignores her plea. In this case the opposite situation occurs: the failure to sympathise with the prisoner is not a question of gender but politics, which has superseded the policewoman's femininity (Aliaga 1992: 84). The gender identity of both women is ultimately put into question: the policewoman has been desexed by a politicised and divided society and the woman detainee by the policeman, who, as a man in a position of power, is a representative of the male-centred state. Female prisoners, female prison officers, and policewomen stepped outside the traditional roles expected of their gender and. therefore, it is not surprising that male-authored prison narratives tend to either ignore them or desex them. The female detainee in "A Curse" subverts that tendency. She cannot be masculinised by the policeman and female officer because her period unavoidably stresses her female nature. On the contrary, the female officer is desexed because she is a representative of the state authority that has repressed her female identity. It is the suppression of her gender identity that prevents her from sympathising with another woman in a humiliating situation that only women can experience and relate to. The polarity in the representations of these female characters is politically symbolic. Even though Murphy has been critical of the republican movement regarding gender issues, ${ }^{9}$ as a former republican prisoner she seem to share the republican view that being on the authority's side also means to be on the oppressor's side; this would explain why she has opted for masculinising the officer.

Preconceived notions of female incarceration result from social constructs of gender and femininity. Italian criminologists Cesare Lombroso and Guglielmo Ferrero claimed in the nineteenth century that women were less prone to commit crime because "women's reproductive role meant that they had a tendency to 'perpetuation' rather than 'development' and as such their maternal function produced superior powers of endurance, primitive intelligence and resistance to mental

9. For example, in the short story "A Social Call" and the play A Night with George (2011). and physical pain, whilst men surpassed them because of their active drive ('passion') in evolutionary competition" (Corcoran 2006: 645). Although essentialist theories based on gender stereotypes like this one are unacceptable today, it is still possible to detect traces of their influence in representations of female prisoners as pathological and deviant women who have transgressed the boundaries of what is traditionally considered feminine. Female political prisoners in Northern Ireland transgressed gender boundaries and challenged traditional constructs of femininity. By using menstrual blood as political weapons in the nowash protest, women prisoners were not only confronting the dissociation of women (and their bodies) from politics, but they were also rejecting the idea of femininity associated with purity by both Protestant and Catholic religious cultures. Menstruation is a clear mark of femininity that inevitably stresses female identity and Murphy recognises this with her references to menstrual blood in "A Curse" and "Human Waste". Her prison short stories foreground a topic many found uncomfortable and preferred to ignore.

\section{Subverting Mother Ireland}

The most common and influential female image associated with Irish nationalist discourses has been that of Mother Ireland (also known as Hibernia, Cathleen ni Houlihan or Shan Van Vocht), a woman that mourns the death of her sons who sacrifice their lives in the name of the country. The origins of Mother Ireland can be tracked back to the use of aisling in the seventeenth and eighteenth centuries. Aisling was a Gaelic poetic genre in which Ireland appears in the form of a woman who laments the state of the country but also foresees a chance in the fortune of the Irish people. A century later this mythic figure started to appear in English-written poems (James Clarence Mangan's "Dark Rosaleen") and soon coupled to the image of the Virgin Mary. In "Feminist Articulations of the Nation", Laura Lyons explores the connection between Mother Ireland and the Virgin Mary that emerged in the mid-nineteenth century. According to Lyons, the Virgin Mary had been portrayed as "the active protectress of Ireland" until the Great Famine when it changed from protectress to Mater Dolorosa - the suffering 
mother of Jesus Christ -, who became a model for Irish women (1996: 114). As a result of the nationalist fervour that increased "from the time of the famine through the first two decades of the twentieth century, this image of the sorrowful Virgin gained both in prominence and political significance" (Lyons 1996: 115). In the literary panorama of the early twentieth century, Mater Dolorosa merges with political personifications of Ireland as a woman. Padraig Pearse's mother in "The Mother" and W.B. Yeats and Lady Gregory's Cathleen in Cathleen ni Houlihan are examples of this hybrid figure. Even writers who were critical of romantic notions of Irish nationalism also incorporated features of Mother Ireland in their leading female characters (James Joyce's Molly Bloom in Ulysses, John Millington Synge's Pegeen Mike in The Playboy of the Western World, and Sean O'Casey's Juno in Juno and the Peacock). In Northern Ireland in the second half of the twentieth century, writers like Seamus Heaney, Paul Muldoon or Bernard McLaverty - among many others - and especially popular fiction writers made substantial use of the figure of Mother Ireland to portray women in connection with the Troubles. In "Mothers, Whores, and Villains", Bill Rolston argues that most Troubles fiction has represented women as either pure, passive and caring mothers or as 'whore mothers', a term taken from Shaun Herron's The Whore Mother (1974) to illustrate "the metaphor of Mother Ireland as a murderous seductress" who incites men to violence and rebellion (1989: 48). Hence, male Troubles writing has often portrayed women as either heroic suffering mothers along the lines of O'Casey's Juno or seductress women along the lines of Yeats and Gregory's Cathleen.

The glorification of a feminised Ireland has been repressive for Irish women, who were expected to live up to this image and be passive mourners or inciters rather than active participants of the nationalist struggle. Nonetheless, in the last decades of the twentieth century Irish women began to object to a female model that denied their realities and relegated them to the margins. In the late 1980s a younger generation of Northern Irish women started to claim a place in political and militant republicanism as they no longer identified with this pure, virginal, subdued and politically passive figure. Women writers also contributed to undermining the discourse of Mother Ireland which so often appeared in male-authored writing. Rebecca Pelan argues that "the images of women in Irish fiction by men are basically so powerful, albeit mythical, that they can only be countered by realistic figures" (2005: 129). Realistic approaches to femininity were marginalised because the emphasis was always on women as symbolic representations of the nation. A number of women writers, however, have turned to realism in order to successfully challenge those symbolic representations.

The short story female writers considered in this article are good examples of how female writing has favoured realistic explorations of feminine psychologies and sociologies over allegorical ones. Their female characters are not symbolic but realistically drawn figures depicting real women in similar situations. It is possible to trace some of the characteristics of Mother Ireland in Beckett's and Molloy's female characters - after all, they are suffering mothers and passive victims of the Troubles but their stories fundamentally aim to create realistic representations of Irish women that challenge patriarchal notions of femininity. The mothers in "The Master and the Bombs" and "The Man of the House", for example, occasionally go against the traditional concepts of motherhood, although never to the extent of becoming 'whore mothers' who encourage their children to participate in the conflict. Likewise, they are not devoted wives; they resent and rebel against the heroic status their husbands have gained from internment, thus deconstructing the male ideal of republican heroism. Their struggle for survival, like the struggle of the female protagonists in "Dancing with My Daddy", is portrayed as more heroic than their men's political crusade. Murphy's " $A$ Curse" and "Human Waste" also subverts the discourse of Mother Ireland. The women prisoners in these stories not only challenge the patriarchal constructs of femininity within the British state but also the dominant republican and Catholic models of femininity. The menstrual blood imagery in these stories inevitably negates the model of "the asexual Catholic mother" (Aretxaga 1995: 140) modelled after the Virgin Mary, a negation which is also suggested in Beckett's and Molloy's stories with their allusion to female reproduction. 
Beckett, Molloy and Murphy subvert malecentred readings of incarceration by focusing on female experiences which have generally been excluded from public discourse. The material and gender difficulties that their female characters encounter are the result of "nationalist and/or Republican ideology as well as state and colonial intervention" (Sullivan 1999: 68). These writers use incarceration as a medium to expose how state politics has oppressed and undermined female identity while also calling into question the models of the rebel-hero and Mother Ireland constructed by the nationalist and republican movements. Their stories challenge traditional discourses of masculinity and femininity and illustrate how national politics is superseded by gender politics in Northern Irish women's writing. They are excellent proof of an emerging gender consciousness which destabilises the dominant narratives of the Troubles. Unfortunately, these responses are limited to nationalist and republican experiences because there are no prison short stories about women from the other side of the divide. Short stories about Protestant women would have helped to shed more light on women's experiences of incarceration and women writers' responses to it; however, the existing prison short stories already provide ample insight worth of acknowledgement and attention.

\section{Works Cited}

Aliaga Rodrigo, Esther. 1992. "Mujeres y violencia en Irlanda del Norte. Reflejo literario en las narraciones cortas de Fiona Barr y Brenda Murphy”. Asparkia: Investigació Feminista, 8. 73-88. Castelló: Universitat Jaume I.

Aretxaga, Begoña. 1995. “'Dirty Protest': Symbolic Overdetermination and Gender in Northern Ireland Ethnic Violence". Ethos, 23.2. 123-48. Berkeley: U of California P.

1997. Shattering Silence: Women, Nationalism, and Political Subjectivity in Northern Ireland. Princeton: Princeton U P.

Beckett, Mary. 1980. "The Master and the Bombs". A Belfast Woman. New York: William Morrow and Company. 101-10.

Carr, Ruth. 1998. "About the Stories". Women Are the Scourge of the Earth. Frances Molloy. Belfast: White Row P.16-20.

Corcoran, Mary. 2004. "WWe had to be stronger': The Political Imprisonment of Women in Northern Ireland, 1972-1999”. Irish Women and Nationalism: Soldiers, New Women and Wicked Hags. Ed. Louise Ryan and Margaret Ward. Dublin: Irish Academic P. 114-31.

2006. Out of Order: The Political Imprisonment of Women in Northern Ireland 1972-1998. Cullompton: Willan Publishing.

2007. "Normalization and its Discontents: Constructing the 'Irreconcilable' Female Political Prisoners in Northern Ireland". British Journal of Criminology, 47.3. 405-422.

D’Arcy. Margaret. 1981. Tell Them Everything: A Sojourn in the Prison of Her Majesty Queen Elizabeth II at Ard Macha (Armagh). London: Pluto P.

Edge, Sarah. 1995. "Representing Gender and National Identity". Rethinking Northern Ireland: Culture, Ideology and Colonialism. Ed. David Miller. London: Longman.

Fairweather, Eileen, Roisín McDonough and Melanie McFadyean. 1984. Only the Rivers Run Free. Northern Ireland: The Women's War. London and Sydney: Pluto P.

Lyons, Laura. 1996. "Feminist Articulations of the Nation: The "Dirty" Women of Armagh and the Discourse of Mother Ireland". On Your Left: Historical Materialism in the 1990s. Ed. Ann Kibbey, Thomas Foster, Carol Siegel, and Ellen e. Berry. New York U P. 110-49.

McAuliffe, Mary and Laura Hale. 2010. “'Blood on the Walls': Gender, History and Writing the Armagh Women”. Irish Women at War: The Twentieth Century. Ed. Gilliam McIntosh and Diane Urquhart. Dublin: Irish Academic P. 171-86.

McCafferty, Nell. 1981. The Armagh Women. Dublin: Co-op Books.

1994. "It Is My Belief That Armagh Is a Feminist Issue". Ireland's Women: Writings Past and Present. Ed. Katy Donovan. Dublin: Gill and McMillan. 19-22. 
McKearney, Tommy. 2011. "Internment, August 1971: Seven Days that Changed the North". History Ireland, 19.6. 32-5.

Maguire, John. 2008. IRA Internments and the Irish Government: Subversives and the State, 1939-1962. Dublin: Irish Academic P.

Molloy, Frances. 1998a. "Dancing with My Daddy". Women Are the Scourge of the Earth. Belfast: White Row P. 38-54.

1998b. "The Man of the House". Women Are the Scourge of the Earth. 68-71.

Murphy, Brenda. 1985. “A Curse”. The Female Line: Northern Irish Women Writers. Ed. Ruth Hooley. Belfast: Northern Ireland Women's Rights Movement. 40-1. 1988. "Human Waste". The Blackstaff Book of Short Stories. Belfast: Blackstaff. 51-5.

Parker, Michael, ed. 1995. The Hurt World: Short Stories of the Troubles. Belfast: Blacksatff P.

Pelan, Rebecca. 1974. "Public Attitudes to Internment". Fortnight, 88. 6-8.

2005. Two Irelands: Literary Feminisms North and South. New York: Syracuse U P.

Rolston, Bill. 1989. "Mothers, Whores, and Villains: Images of Women in Novels of the Northern Irish Conflict". Race and Class, 31. 41-57.

Shannon, Elizabeth. 1989. I Am of Ireland: Women of the North Speak Out. Boston: Little, Brown and Company.

Sullivan, Megan. 1999. Women in Northern Ireland: Cultural Studies and Material Condition. Gainesville: U P of Florida.

Received $10^{\text {th }}$ January $2013 \quad$ Last version $30^{\text {th }}$ August 2013

Mercedes del Campo del Pozo is a final year PhD student at University of Ulster researching a thesis on Troubles and post-Troubles short fiction by women writers from Northern Ireland. She holds an MA in Irish Writing from Queen's University Belfast and an MPhil in English from Universidad de Valladolid. Her main research interests are in modern and contemporary literature and culture and in artistic and literary representations of war trauma, social conflict, post-war periods and conflict resolution. She is particularly interested in the literature of the Northern Irish Troubles and the Spanish Civil War. 